\title{
Societal sustainability: The contribution of adult education to sustainable societies
}

\author{
Marcella Milana ${ }^{1} \cdot$ Palle Rasmussen ${ }^{2}$. \\ John Holford ${ }^{3}$
}

Published online: 21 September 2016

(C) Springer Science+Business Media Dordrecht and UNESCO Institute for Lifelong Learning 2016

\section{Introduction: how adult education contributes to sustainable societies}

The idea for this special issue arose from the Second Conference of the Network on Policy Studies in Adult Education (active under the European Society for Research on the Education of Adults, ESREA), held in Aalborg, Denmark, on 18-20 June 2014. The theme of the conference was "Interrogating Sustainability in Adult Learning Policy". At this conference, the question of how sustainability is, and could be, integrated into policies for adult learning in the multi-level context of different national, social and cultural environments was thoroughly and vividly discussed in sessions and plenaries.

Accordingly, theoretical and methodological questions arising in studying adult learning policies in national and transnational contexts were also confronted, and the concept of sustainable development itself was critically interrogated.

We (Marcella Milana, Palle Rasmussen and John Holford; guest editors of this special issue) furthered these discussions in the symposium "Adult Education and Learning Policy for Societal Sustainability", hosted by the 2015 European Conference of Educational Research (ECER) held in Budapest on 10 September. It was organised in collaboration between the ESREA Network on Policy Studies in

Marcella Milana

marcella.milana@univr.it

Palle Rasmussen

palleras@learning.aau.dk

John Holford

john.holford@nottingham.ac.uk

1 Department of Human Sciences, University of Verona, Verona, Italy

2 Department of Learning and Philosophy, Centre for Education Policy and Evaluation Research, Aalborg University, Aalborg, Denmark

3 School of Education, University of Nottingham, Nottingham, UK 
Adult Education and Network 23 on Policy Studies and Politics of Education (operating under the European Educational Research Association, EERA). The insightful discussions among the participants of this seminar further inspired the idea of this special issue. It led to the decision to focus on the acknowledgement that recent social and economic crises have revealed the fragility of existing institutions and policies, and that development of sustainable policies and practices for adult and lifelong education has become vital. The main theme for this special issue, Societal Sustainability, thus signals a double implication for adult education: the contribution of adult education to sustainable societies, and the development of sustainable policy frameworks for adult education.

Correspondingly, we invited a few colleagues with convergent interests in the contribution of adult education to sustainable societies, and whose perspectives were first presented at either the Aalborg conference or the Budapest symposium, to contribute papers on this topic. We complemented this collection with one article by a colleague who, though he had intended to, had been unable to join either of these events. Finally, but not less importantly, this collection of articles met with the approval of the Editorial Board of the International Review of Education - Journal of Lifelong Learning (IRE), and the IRE Executive Editor, Stephen Roche.

Centring attention on societal sustainability and the ways in which adult education contributes to sustainable societies became even more pregnant with significance when the post-2015 agenda set new Sustainable Development Goals (SDGs), encouraging debates on the role of adult education in achieving these goals. As Aaron Benavot, the Director of UNESCO's Education for All Global Monitoring Report, ${ }^{1}$ notes:

Adults have a prominent place in the SDGs; if we disassemble some of the assumptions (whether explicit or implicit), transforming adults, their attitudes, behaviour and lifestyles are deeply embedded in the other SDGs, even if it not as explicitly in SDG 4 [i.e. Ensure inclusive and equitable quality education and promote lifelong learning opportunities for all]. Exploring what the role of adult learning and education would be in contributing to the other goals, if the assumptions are unpacked, would be a valuable exercise, since there is no existing analysis that carefully considered the implications of different SDGs on education, and specifically for the world of ALE [i.e. Adult Learning and Education] (Benavot 2016). ${ }^{2}$

However, our particular concern in this special issue is SDG 16, which aims to "promote peaceful and inclusive societies for sustainable development, provide access to justice for all and build effective, accountable and inclusive institutions at all levels" (UN 2015). ${ }^{3}$ It is this goal which should inspire and serve as stimulation

\footnotetext{
${ }^{1}$ In the course of the recent replacement of the 8 Millennium Development Goals (MDGs) to the 17 Sustainable Development Goals (SDGs), UNESCO has now re-named this series of reports Global Education Monitoring Report (GEM).

2 Benavot, A. (2016). Presentation given at the Uppingham Seminar "Adult Learning and the Sustainable Development Goals", Midhurst, Sussex, 7-9 April 2016. Retrieved 15 August 2016 from http://www. uppinghamseminars.co.uk/Aaronspresentation.pdf.

${ }^{3}$ UN (United Nations) (2015). Sustainable Development Goal 16 [online resource]. Retrieved 15 August 2016 from http://www.un.org/sustainabledevelopment/peace-justice.
} 
for scholarly debates around the links between adult education and sustainable societies.

We (Marcella Milana, Palle Rasmussen and John Holford) elaborate on this position, and lay out some conceptual frames for its development, in the opening article to this collection, entitled "The role of adult education and learning policy in fostering societal sustainability". We argue that the idea of "sustainability" as a core value has slowly permeated policy and practice at governmental and institutional levels, in public and private policy, but that recent social and economic crises have revealed the fragility of both institutions and policies. Therefore, it is important to debate how sustainability can be interpreted and researched in the context of education policy studies, and how this research can contribute to a sustainable future. Our article begins with a summary of the conditions under which the concept of "sustainability" entered the political debate and how it has influenced educational research. We then question limited versions of sustainability policies, such as Corporate Social Responsibility (CSR), and contrast them with historical and general frameworks for social and inter-generational justice in education. We argue that pursuing such justice in sustainable ways calls for looking at the ecology of educational systems, the mutual links education systems hold with multiple life-settings, and the forces which influence these settings.

The subsequent five articles contribute analyses and perspectives on the theme from socio-cultural contexts and researchers located in different parts of the world.

In "The misuses of sustainability: Adult education, citizenship and the dead hand of neoliberalism" John Holford goes back in history to examine examples of adult education in the Anglophone world and their implications for our understanding of sustainability. He argues that a particular discourse of "sustainability", strongly inspired by business approaches, is currently regarded as common sense and that it undermines critical analysis and understanding of 20th-century adult education. This discourse, he argues, encourages the presumption that when educational programmes and movements have died out, this is because they were unsustainable and had failed to adapt to new situations and conditions. They are thus seen to be responsible for their own demise. The author then challenges this presumption by giving three examples of adult education: (1) English liberal adult education; (2) the policy of "mass education" (also known as community development) in the British colonies; and (3) UNESCO's programme of Fundamental Education. In each case he demonstrates that their discontinuation was not a result of "unsustainability" in the business sense, but rather due to a more complex combination of factors strongly involving external political intervention.

A contribution from a different part of the Anglophone world is "Sustainable development and social learning: Re-contextualising the space of orientation" by Terri Seddon. Her article contrasts the often dramatic rhetoric on climate change in Australian politics with hesitant government action and limited public awareness of the need to act, and asks how educators might help to make sustainable futures in such a context. Drawing on the concept of "space of orientation", the author discusses how historical context entangles social learning in ways which complicate policies associated with Education for Sustainable Development (ESD) as well as practices of Education for Sustainability (EfS). She traces contradictions between 
"globalisation" and "sustainability" in Australian adult education through policy logics, relational practices, and in the "necessary utopia", which provides a point of reference for making futures. She argues that spaces of orientation are a critical resource when humanity faces intensifying conflicts of interest between economic priorities of globalisation and environmental priorities of slowing down global warming, because they can mediate context and orient learning in ways which steer a path towards sustainability through the entangled histories of this present.

The next article, "Ecopedagogy as an element of citizenship education: The dialectic of global/local spheres of citizenship and critical environmental pedagogies" by Greg William Misiaszek contributes research and perspectives from Latin America. He argues that, given the inherent global effects of both environmental ills and individuals' multiple civil rights and responsibilities, there is a worldwide need to reinvent current environmental pedagogical models. Ecopedagogy, defined as critical, transformative environmental pedagogy centred on increasing social and environmental justice, is a response to this. Emerging from popular education movements in Latin America, eco-pedagogies focus on teaching the connections between environmentally harmful acts by humans and social conflicts which are most often politically hidden in formal as well as non-formal and informal education. On the basis of comparative research about expert ecopedagogues in Argentina, Brazil and Appalachia (USA), and highlighting teaching and policy aspects of eco-pedagogy in these three locations which have seen strong historical popular education movements, the author argues that there is a need for a paradigm shift towards eco-pedagogical models in environmental teaching and research as well as in citizenship education. However, intensifying processes of globalisation complicate the mechanisms of achieving such a paradigm shift and decentre traditional nation-state citizenship from local to global spheres, and this must be reflected in the theory and practice of eco-pedagogy.

The Nordic countries are an example of a historical trajectory combining democratic welfare state models with economic competitiveness and growth. In this context, sustainability is still a challenge, as shown in the article "Adult education and the challenges of regional development: Policy and sustainability in North Denmark" by Palle Rasmussen and the late Hans Jorgen Staugaard. The article focuses on the dilemmas of adult education policy in a regional context, more specifically the North Denmark region of the Danish nation-state. The authors argue that this region is facing the same challenges as most other regions in industrialised countries, because a significant part of the population - mainly males, and mostly living in the peripheral parts of the region - has a low level of educational qualifications while there is a rapidly increasing demand for skills and qualifications. Adult education is an obvious response to this, and the article traces the adult education strategies of the local authorities and the educational institutions, and discusses their ability to cope with the challenges. While Denmark has a developed and versatile system of adult education, the strategic capacity of local actors seems circumscribed by the systems of funding and governance influenced by New Public Management as well as by limited awareness of the potential of adult education to contribute to societal sustainability. 
While finishing this special issue, we received the sad news that one of the authors, Hans Jørgen Staugaard, had passed away in July 2016. Hans Jørgen was an active teacher and researcher with personal and professional integrity. He made significant contributions to critical research on adult education and on the professions. He will be missed by many.

The education policies of the Nordic countries are also a theme in the contribution which closes this collection, but here they are related to the Asian world. The article "Lifelong guidance: How guidance and counselling support lifelong learning in the contrasting contexts of China and Denmark" by Zhixin Zhang focuses on guidance as a key element in lifelong learning and compares systems and practices of guidance in Denmark and China. She outlines the societal factors which make lifelong learning provision necessary and situates guidance in this context. The author then compares policies and systems of guidance in the two countries. She describes the international and national backgrounds and presents and discusses the evolution of guidance and the different elements of provision in each of the two countries. Part of the purpose of her analysis is to gain inspiration from the Danish context for further developing guidance systems and practices in China. A key suggestion is to strengthen the professionalisation of guidance in China by means of establishing a professional degree in guidance and counselling.

Taken together, the six articles which compose this special issue provide conceptual and empirical readings of past, present and possible future relationships which societal sustainability holds with adult education. Different contributions from the Anglophone world, Latin America, a welfare-state model society like Denmark, and finally China, highlight significant failures in education policy to learn from the history of adult education as a social institution which has contributed to issues of social progress, equity and justice. Further, they present novel perspectives enabling us to make sense of the past and the present by bringing to the fore alternative epistemologies, which deconstruct anthropocentric standpoints on human existence and development. In short, the contributions presented in this special issue show that adult education has already contributed to societal sustainability, but could contribute much more in the future, provided it is not subjugated by the kind of economic rationales and ideologies which are feeding much of the contemporary discourse on sustainable development on national and global scales.

\section{The authors}

Marcella Milana is Associate Professor in Education at the University of Verona, Italy, where she directs the International Research Centre for Global and Comparative Policy Studies on the Education and Learning of Adults (IRC-GloCoPoS). A joint editor of the International Journal of Lifelong Education, and a convenor of the ESREA Research Network on Policy Studies in Adult Education, she has been writing about participation in adult education, adult education for democratic citizenship, the professionalisation of adult educators, adult education policy, and the work of international organisations. Her recent work includes Global networks, local actions: Rethinking adult education policy in the 21th century (Routledge, 2016). 
Palle Rasmussen is Professor of Education and Learning Research in the Department of Learning and Philosophy, Aalborg University, where he directs the Centre for Education Policy and Evaluation Research. His research areas include education policy, lifelong learning and evaluation methodology and he has published extensively in these fields. A recent publication (co-authored with Bengt-Åke Lundvall) is "Challenges for adult skill formation in the globalising learning economy - a European perspective" (International Journal of Lifelong Education, July 2016). He is a member of the Danish National Research Council for Communication and Culture and also a member of the scientific board of the European Cooperation in Science and Technology (COST).

John Holford is Robert Peers Professor of Adult Education at the University of Nottingham, UK, and joint editor of the International Journal of Lifelong Education. His research has focused chiefly on the role of lifelong education in the formation of citizens, communities and social movements. His recent books include Adult Education Policy and the European Union (editor, with Marcella Milana, Sense Publishers 2014), and Lifelong Learning in Europe: National Patterns and Challenges (editor, with Ellu Saar \& Odd Bjørn Ure, Edward Elgar Publishing 2013). He is also joint convenor of the European Society for Research on the Education of Adults (ESREA) Network on Policy Studies in Adult Education, and Co-ordinator of the Horizon 2020 project "Encouraging Lifelong Learning for an Inclusive and Vibrant Europe" (ENLIVEN). 